\title{
Turnover of dead jellyfish: stimulation and retardation of microbial activity
}

\author{
Josefin Titelman ${ }^{1, *}$, Lasse Riemann ${ }^{2}$, Tom A. Sørnes ${ }^{1}$, Trygve Nilsen ${ }^{3}$, \\ Petra Griekspoor ${ }^{2}$, Ulf Båmstedt ${ }^{1,4}$ \\ ${ }^{1}$ Department of Biology, University of Bergen, PO Box 7800, 5020 Bergen, Norway \\ ${ }^{2}$ Department of Natural Sciences, Kalmar University, 39182 Kalmar, Sweden \\ ${ }^{3}$ Department of Mathematics, University of Bergen, PO Box 7800, 5020 Bergen, Norway \\ ${ }^{4}$ Umeå Marine Science Centre, University of Umeå, Norrbyn, 91020 Hörnefors, Sweden
}

\begin{abstract}
Little is known about the fate of jellyfish biomass after their populations crash. We measured turnover rates of dead Periphylla periphylla in a pelagic in situ experiment in Raunefjorden, Norway. Decay was exponential, with decay-coefficients of 0.67 to $1.12 \mathrm{~d}^{-1}$; smaller jellyfish turned over faster than larger ones. The rapid turnover suggests that large amounts of carbon and nitrogen are transferred to the pelagic and/or benthic foodwebs at the collapse of jellyfish blooms. The interactions between bacteria and dead jellyfish were examined in a shipboard experiment in Lurefjorden, Norway, using natural bacterial assemblages. Growth and morphology of the bacteria in the incubations suggested that only certain morphotypes proliferated in the vicinity of jellyfish tissue. Subsequent experiments with homogenized $P$. periphylla tissue and bacterial isolates from various phylogenetic groups confirmed that some bacteria could use jellyfish as substrate, while others were inhibited. Tests with sensitive isolates revealed that inhibition of bacterial growth depended on the body part, size and concentration of $P$. periphylla used. Because only some bacteria were able to use $P$. periphylla as a substrate, we suggest that the role of dead jellyfish as trophic links in specific pelagic foodwebs depends partly on bacterial community composition.
\end{abstract}

KEY WORDS: Periphylla periphylla $\cdot$ Degradation $\cdot$ Bacteria $\cdot$ Inhibition $\cdot$ Growth

Resale or republication not permitted without written consent of the publisher

\section{INTRODUCTION}

Although many fish, turtles, birds and invertebrates feed on jellyfish, top-down trophic control of jellyfish populations is often lacking, and populations may therefore grow large (Arai 2005). This pattern, combined with the reputation of jellyfish as voracious predators of zooplankton (Purcell \& Arai 2001, Purcell \& Decker 2005), other jellyfish (Purcell 1997), fish eggs and larvae (Purcell \& Arai 2001), has led to the traditional view of jellyfish representing trophic dead ends or sinks in pelagic foodwebs (Hansson \& Norrman 1995, Arai 2005). Although challenged, some reports suggest that jellyfish biomass has increased in the past decades (Mills 2001), and that jellyfish biomass may be linked to climatic variability and change (Brodeur et al.
1999, Lynam et al. 2004, Purcell 2005, Purcell \& Decker 2005). In any case, mass-occurrences of jellyfish are common, often seasonal, features of many coastal systems (Schneider 1989, Hansson 1997, Mills 2001) and may contribute substantially to the carbon standing stock of planktonic foodwebs (e.g. Schneider 1989, Graham et al. 2001). Yet the fate of the carbon and nutrients bound in these populations after their crashes is unknown.

Bacteria thrive in the dissolved organic carbon (DOC) released by live jellyfish, both in the laboratory (Hansson \& Norrman 1995) and the field (Riemann et al. 2006, this volume). We therefore expect that dead jellyfish return energy and nutrients to the foodweb via rapid degradation and remineralization processes in the water column and on the seafloor by components of the microbial loop. 
Other gelatinous material, such as abandoned appendicularian houses and other marine snow particles provide both food and habitats for microbes and larger animals (e.g. Alldredge 1972, Kiørboe 2000). Small structures, such as houses from the appendicularian Oikopleura dioica, may be completely disintegrated in deep water columns (Davoll \& Silver 1986), or sink to the bottom at speeds exceeding $100 \mathrm{~m} \mathrm{~d}^{-1}$ in shallower environments (e.g. Hansen et al. 1996). Stemman et al. (2004) estimated that $90 \%$ of the particles $<1 \mathrm{~cm}$ are remineralized within the euphotic zone in oceanic environments. In contrast, in the Gulf of Oman, dead jellyfish (Crambionella orsini) have been observed by video to roll down the continental slope and form meter sized benthic patches at $3300 \mathrm{~m}$ depth (Billet et al. 2006). Direct measurements of degradation rates of larger, dead gelatinous zooplankton are scarce, and little is known about the contribution of dead jellyfish to the pelagic nutrient pool. Larger live medusae accumulate damage through the season and are gradually broken down in the water column (Mills 1993). Mesocosm experiments with the moon jellyfish Aurelia aurita suggest pelagic turnover rates of $\sim 4$ to 5 days (Hansson 1997). This result implies that turnover rates may be sufficiently high to make jellyfish quantitatively important as nutrient sources during breakdown of blooms.

In Lurefjorden, western Norway, the coronate scyphomedusa Periphylla periphylla abounds year round and performs daily vertical migrations between the surface and several hundred meters (Fosså 1992, Youngbluth \& Båmstedt 2001, Sørnes 2005). This makes $P$. periphylla well suited for experiments where large quantities of similarly sized animals are needed. Here, we used $P$. periphylla to study the degradation of dead gelatinous zooplankton. We quantified turnover rates of dead medusae through time in a pelagic in situ experiment and conducted a shipboard experiment that targeted the microbial activity associated with decaying jellyfish. A final series of laboratory incubations using bacterial isolates was executed to further assess positive and negative effects on specific bacterial species. In a companion paper, we examined the distribution of bacterial activity and microbial community composition relative to jellyfish biomass in Lurefjorden (Riemann et al. 2006).

\section{MATERIALS AND METHODS}

We carried out a series of experiments aimed at quantifying decomposition rates of various sizes of jellyfish in an in situ pelagic setting, as well as a series of shipboard and laboratory experiments investigating the interactions between dead jellyfish and the microbial community.
In situ degradation experiment. Experimental setup: Periphylla periphylla were collected with a MIK net ( $2 \mathrm{~m}$ mouth diameter, 1 to $3 \mathrm{~mm}$ graded mesh) between $300 \mathrm{~m}$ and the surface in the deep basin of Lurefjorden, on 8 October 2003. On board the ship the jellyfish were emptied into clean, water filled buckets and stored at $5^{\circ} \mathrm{C}$ in darkness during transport back to the laboratory. $P$. periphylla were weighed individually (wet weight, to nearest $0.1 \mathrm{~g}$ ) and placed individually in tagged nylon mesh bags ( $80 \%$ polyamide, $20 \%$ elastane). The bags stretched with their contents and had a mesh size of $\sim 5$ to $10 \mathrm{~mm}$. This large mesh size allowed for colonization of both microbes and zooplankters, while ensuring transport of solutes and materials to the surrounding water. The bags were horizontally spaced at approximately $30 \mathrm{~cm}$ intervals and suspended individually at 1 or $8 \mathrm{~m}$ depth with fishing lines from the mesocosm platform in Raunefjorden, off Espegrend Marine Biological Station. These depths represented 2 different temperatures; mean temperature $( \pm \mathrm{SD})$ was $10.1 \pm 0.5^{\circ} \mathrm{C}$ at $1 \mathrm{~m}$ and $12.5 \pm 0.1^{\circ} \mathrm{C}$ at $8 \mathrm{~m}$. A small lead weight anchored the bag in the water. A total of 250 jellyfish, equally divided between 4 size categories $(42.6 \pm 8.14,121 \pm 12.3,223 \pm 12.3$ and $300 \pm 36.1 \mathrm{~g}$, mean $\pm \mathrm{SD}$ ), were suspended, with the 3 smallest categories at the shallower depth. The size groups were chosen such that their initial weights did not overlap. We estimated that this number of jellyfish would allow for daily sampling for several weeks if needed, while allowing for randomization of samples. Because we needed to process many individuals, the time from capture until the last jellyfish had been suspended was approximately $12 \mathrm{~h}$. Temperature and salinity were monitored throughout the study period.

At each daily sampling, 3 jellyfish of each size category were gently pulled to the surface and weighed in their bags, but without the line, weight and label. Wet weights were subsequently corrected for bag weight (mean $\pm \mathrm{SD}, 14.8 \pm 0.62 \mathrm{~g}$ in seawater, $\mathrm{n}=7$ bags), and the rate of change in wet weight was used as a proxy for degradation rates. The largest jellyfish were homogenized and frozen for subsequent determination of carbon and nitrogen content. Sampled jellyfish were discarded.

Carbon and nitrogen analysis: Known volumes of jellyfish homogenate were collected on precombusted $\left(450^{\circ} \mathrm{C}\right.$ for $\left.4 \mathrm{~h}\right)$ Whatman GF/F filters. The filters were analyzed with a Carlo Erba model 1108 high-temperature combustion elemental analyzer, using standard procedures and a combustion temperature of $1030^{\circ} \mathrm{C}$. Acetanilide was used for standardization and results were corrected for carbon content of blank filters. The first sample was taken after $6 \mathrm{~h}$.

Shipboard experiments. We conducted 2 shipboard experiments in Lurefjorden to investigate the de- 
velopment of bacteria around dead Periphylla periphylla.

Experimental set-up: In the first experiment we incubated 6 large dead Periphylla periphylla $(101 \pm 13.6$ g, mean $\pm \mathrm{SD}$ ) individually in $5 \mathrm{l}$ containers and monitored the development of the bacterial community. We also included 3 controls without $P$. periphylla. In the second experiment, we monitored bacterial abundance in 21 containers with individual small $(31.0 \pm 1.0 \mathrm{~g}$, mean \pm $\mathrm{SD}, \mathrm{n}=3)$ or medium $(63.8 \pm 6.0 \mathrm{~g}, \mathrm{n}=4)$ dead P. periphylla and in 5 controls without $P$. periphylla. The setups for both experiments were similar, and the experiments were conducted in parallel in Lurefjorden on 23 to 25 April 2004. All materials were acid washed in $1 \mathrm{M}$ $\mathrm{HCl}$, and gloves were used at all times.

Sterile seawater for the incubation experiments was obtained by filtering seawater from $\sim 100 \mathrm{~m}$ depth in Lurefjorden, obtained with a Rosette sampler, through a polypropylene capsule filter (5 to $10 \mu \mathrm{m}$ nominal pore size, Advantec MFS) followed by a $0.22 \mu \mathrm{m}$ capsule filter (Millipak-40, Millipore). Prior to filtration, the virgin capsule filters were flushed with $\sim 51$ Milli-Q. The containers were inoculated with a $10 \%$ volume of surface $(5 \mathrm{~m})$ seawater, which had been $1.0 \mu \mathrm{m}$ filtered (polycarbonate, MSI) to remove flagellates. The total volume was $4820 \mathrm{ml}$ for the large and $1650 \mathrm{ml}$ for the small containers.

Small and medium sized Periphylla periphylla were caught in MIK nets between $300 \mathrm{~m}$ and the surface. Larger specimens were scooped up directly from the surface water with buckets at night. We selected healthy looking intact animals and suffocated these in air for half an hour before the start of the experiment. At this time the jellyfish were also weighed and measured. The jellyfish were rinsed in 3 successive baths of $0.2 \mu \mathrm{m}$ filtered seawater and subsequently added to the pre-filled containers. We denoted this $t=0$. The experimental chambers were gently aerated to ensure oxic conditions and covered at all times to prevent light-generated breakdown of the porphyrin of the P. periphylla. The containers were partly submerged in a flowing surface-water-bath with a temperature of 10 to $11.5^{\circ} \mathrm{C}$. The temperature at the inflow and outflow of the water bath was always the same. The ambient water temperature was $\sim 8^{\circ} \mathrm{C}$ at the surface (Riemann et al. 2006).

We monitored the experiments for $\sim 50 \mathrm{~h}$ and sampled approximately every 8 h (i.e. $t=2,10,18,26,33$, 42 and $50 \mathrm{~h}$ ). Samples were taken for determination of bacterial abundance in both the small and large containers (see below). The large containers were also sampled for total organic carbon (TOC), nutrients and bacterial production (see below). The required water volumes for the latter analyses made these unfeasible in the small containers.
Bacterial abundance: Aliquots of 25 (small containers) or $50 \mathrm{ml}$ (large containers) were fixed with $0.2 \mu \mathrm{m}$ filtered formalin and stored at $4^{\circ} \mathrm{C}$ for one month before bacterial enumeration. Bacteria in samples from the control incubations without added jellyfish were stained with SYTO 13 (Molecular Probes) and counted on a Becton Dickinson FACSCalibur flow cytometer (Gasol \& del Giorgio 2000) using fluorescent beads (True counts, Becton Dickinson) as standards. In incubations with jellyfish, interference from released jellyfish cells prevented enumeration by flow cytometry. Instead, bacteria were stained with SYBR Green I (Molecular probes), filtered onto $0.22 \mu \mathrm{m}$ black polycarbonate filters (Osmonics) and mounted in glycerol (Noble \& Fuhrman 1998). More than 200 bacteria or $>15$ fields filter ${ }^{-1}$ were counted at $1250 \times$ using epifluorescence microscopy (Axioplan, Zeiss). Pictures were taken using an Olympus DP50 camera. To estimate variability among filters, duplicate filters were counted on 3 occasions. The average SD among filters was $6 \%$.

Bacterial production: Bacterial production was measured by $\left[{ }^{3} \mathrm{H}\right]$-thymidine incorporation (Fuhrman \& Azam 1982). For each sample, triplicate aliquots $(10 \mathrm{ml})$ and a fixed blank were incubated with [methyl${ }^{3} \mathrm{H}$ )-thymidine (10 nM final, Amersham Pharmacia Biotech) in polyethylene vials in a water bath with flowing surface seawater for ca. $1 \mathrm{~h}$. Samples with $5 \%$ trichloroacetic acid added prior to the addition of $\left[{ }^{3} \mathrm{H}\right]$-thymidine served as blanks. Samples were filtered onto $0.2 \mu \mathrm{m}$ mixed cellulose ester filters (Advantec MFS), rinsed carefully with ice-cold $5 \%$ trichloroacetic acid and counted by liquid scintillation spectrometry. Bacterial carbon production was calculated using $1.1 \times$ $10^{18}$ cells mole ${ }^{-1}$ thymidine incorporated (Riemann et al. 1987) and a carbon-to-cell ratio of $20 \mathrm{fg} C$ bacterium $^{-1}$ (Lee \& Fuhrman 1987).

TOC: Duplicate $12 \mathrm{ml}$ samples were frozen in $15 \mathrm{ml}$ polypropylene tubes and analyzed with a Shimadzu TOC-5000 high temperature catalytic oxidation instrument. Samples were acidified and sparged prior to analysis. Calculation of carbon concentrations was made using potassium hydrogen phthalate as a standard.

Nutrients: Three $12 \mathrm{ml}$ samples were filtered through glass fiber filters (GF/F, Whatman) into $15 \mathrm{ml}$ polypropylene tubes and frozen for subsequent analysis of ammonia, phosphate and nitrate/nitrite on a Bran \& Luebbe TRAACS 800 autoanalyzer (Grasshoff et al. 1983).

Growth of bacterial isolates in response to Periphylla periphylla. To complement the shipboard experiments, we examined effects of $P$. periphylla on growth of marine bacterial isolates from various phylogenetic groups (Tables 1 \& 2) in a laboratory setting. Generally, overnight bacterial cultures were diluted, 
Table 1. Bacterial isolates used in incubation experiments with Periphylla periphylla homogenate

\begin{tabular}{|c|c|c|}
\hline Name & GenBank accession number ${ }^{\mathrm{c}}$ & Phylogeny \\
\hline BAL3 $^{\mathrm{a}}$ & U63935 & $\alpha$-Proteobacteria \\
\hline BAL11 $^{\mathrm{a}}$ & U63939 & $\alpha$-Proteobacteria \\
\hline BAL18 ${ }^{\mathrm{a}}$ & U63944 & $\gamma$-Proteobacteria \\
\hline BAL203 ${ }^{b}$ & AY962019 & $\gamma$-Proteobacteria \\
\hline BAL37 ${ }^{\mathrm{a}}$ & U63953 & $\beta$-Proteobacteria \\
\hline BAL208 ${ }^{b}$ & AY962020 & Actinobacteria \\
\hline BAL209 ${ }^{b}$ & AY962021 & Actinobacteria \\
\hline BAL22 ${ }^{\mathrm{a}}$ & U63946 & Bacteroidetes \\
\hline BAL17 $7^{\mathrm{a}}$ & U63943 & Bacteroidetes \\
\hline \multirow{2}{*}{\multicolumn{3}{|c|}{$\begin{array}{l}\text { a Isolated by Pinhassi \& Hagström (2000) } \\
\text { bIsolated from the Baltic Sea Proper on ZoBell plates } 17 \\
\text { May } 2004\end{array}$}} \\
\hline & & \\
\hline \multicolumn{3}{|c|}{$\begin{array}{l}\text { "Nucleotide sequences and information can be accessed } \\
\text { via www.ncbi.nlm.nih.gov/Entrez/ }\end{array}$} \\
\hline
\end{tabular}

exposed to $P$. periphylla homogenate (see below), and optical density (OD) was monitored over time. Since the inhibition of bacterial growth observed in the shipboard experiments was suspected to be caused by a proteinaceous toxin (B. Johnston, pers. comm.), we included a control consisting of autoclaved $P$. periphylla homogenate in our set-up. Further, we included a negative control in which the added $P$. periphylla volume was substituted by sterile seawater (salinity = $33 \%$ ), to control for added salt from the P. periphylla tissue.

Periphylla periphylla homogenate: In all experiments, we used homogenate made immediately prior to each experiment. $P$. periphylla were caught in Lurefjorden 12 January 2005. Individual live animals of various sizes and individual body parts were blended with a food processor and immediately frozen in $50 \mathrm{ml}$ Falcon tubes. Immediately prior to each experiment, $P$. periphylla samples were thawed and further homogenized with an Ultra-Turrax T25 (Janke \& Kundel) at $24000 \mathrm{rpm}$ for several minutes. The homogenates were subsequently centrifuged $\left(10000 \times g, 10 \mathrm{~min}, 4^{\circ} \mathrm{C}\right)$ to remove particles, which would otherwise interfere with OD measurements. Half of the supernatant was used untreated and the other half was autoclaved and used as control. Thawed samples and homogenates were stored on ice in darkness during set-up of experiments. The concentration of homogenate was quantified volumetrically, i.e. as ml added homogenate per $\mathrm{ml}$ ready solution, in all experiments. The homogenates were not characterized further.

The use of diluted, non-concentrated homogenates implies that the concentration in the experiments by definition can never exceed concentrations in a real, dead jellyfish. In the experiments with isolates, the homogenate was diluted $~ 8$ to 100 times in the bacterial growth medium depending on the experiment. In nature, concentrations of solutes will build up in the boundary layer around the dead Periphylla periphylla and decrease with distance away from the jellyfish. The concentration will also depend on the amount, size and abundance of dead $P$. periphylla, molecular diffusion and ambient water flow.

General experimental set-up: The general set-up was similar for all experiments with bacterial isolates. While details pertaining only to specific experiments are described in their respective sections below, the general set-up was as follows. Bacterial isolates grown overnight in ZoBell medium (5 g peptone, $1 \mathrm{~g}$ yeast extract, $800 \mathrm{ml}$ filtered seawater, $200 \mathrm{ml}$ Milli-Q water, autoclaved $121^{\circ} \mathrm{C}, 20 \mathrm{~min}$ ) were diluted with fresh ZoBell medium to an OD of 0.04 to 0.06 and aliquoted into autoclaved sodium glass-tubes (VWR 109986-17). Periphylla periphylla homogenate, autoclaved $P$. periphylla homogenate or sterile seawater (negative control) was added to a final volume of $4 \mathrm{ml}$. Bacterial growth, measured as OD directly in the tubes, was monitored over time using a Biowave CO8000 cell density meter (600 nm, VWR). Each measurement was corrected for background OD with a blank sample without bacteria. Separate blanks were used for each treatment ( $P$. periphylla homogenate, autoclaved $P$. periphylla homogenate and seawater [salinity $=$

Table 2. Summary of experiments with bacterial isolates and Periphylla periphylla homogenate

\begin{tabular}{|c|c|c|c|}
\hline Experiment & Isolates & $\begin{array}{l}\text { Final } P \text {. periphylla } \\
\text { concentration }\left(\mathrm{ml} \mathrm{ml}^{-1}\right)\end{array}$ & $\begin{array}{l}\text { Contents of homogenate } \\
\text { (weight of animals used) }\end{array}$ \\
\hline Screening & $\begin{array}{l}\text { BAL3, BAL11, BAL18, BAL203, BAL208, } \\
\text { BAL209, BAL37, BAL22, BAL17 }\end{array}$ & 0.04 & Whole animal (92 g) \\
\hline Concentration & BAL18, BAL208, BAL3 & $0.0125,0.025,0.05,0.10,0.15$ & Whole animal ( 600 g) \\
\hline Body parts & BAL18, BAL208 & 0.05 & $\begin{array}{l}\text { Tentacles from } 5 \text { animals (no } \\
\text { data), tops from } 5 \text { animals (no } \\
\text { data), bodies from } 5 \text { animals } \\
\text { (no data), whole animal ( } 83 \mathrm{~g} \text { ) }\end{array}$ \\
\hline Size & BAL18, BAL208 & 0.05 & Whole animals $(5.9-900 \mathrm{~g})$ \\
\hline
\end{tabular}


$33 \%$ ], as well as for different concentrations of additions when applicable) as optical properties of these 3 treatments differ. All experiments were carried out in triplicate in darkness at room temperature $\left(18\right.$ to $\left.19^{\circ} \mathrm{C}\right)$ on a shaking table. Size and parts of $P$. periphylla specimens, concentration of homogenate and bacteria used in the various experiments are summarized in Table 2.

Screening: In the first experiment, we monitored the growth of 9 different bacterial isolates of various phyla, when exposed to Periphylla periphylla homogenate at a concentration of $0.04 \mathrm{ml} P$. periphylla homogenate $\mathrm{ml}^{-1}$ culture (Table 2). The volumetric concentrations of homogenate used were chosen to approximate concentrations in the shipboard experiment where whole jellyfish were added to 2 to 51 volumes, corresponding to enrichment of $\sim 0.02$ to $0.05 \mathrm{~g} P$. periphylla ml ${ }^{-1}$ seawater. An assumed density of $P$. periphylla of $\sim 1 \mathrm{~g}$ $\mathrm{cm}^{-3}$ was applied in the conversion. The size of the $P$. periphylla used (Table 2) was approximately that of an average $P$. periphylla at the time of capture in Lurefjorden (Riemann et al. 2006). From this experiment, isolates were selected for further experimentation.

Response to increasing concentration of Periphylla periphylla homogenate: We estimated growth of 3 bacterial strains as a function of increasing volumetric concentrations of $P$. periphylla homogenate. 0, 50, 100, 200,400 , or $600 \mu \mathrm{l}$ of homogenate was added to $3.4 \mathrm{ml}$ medium with bacteria (Table 2). Sterile seawater was added to a final volume of $4 \mathrm{ml}$ to ensure similar salt content in all treatments. The $P$. periphylla used here was larger than in the first experiment in order to ensure that all treatments got homogenate from the same animal, i.e. a comparable exposure. OD measurements were conducted using separate blanks without bacteria for each concentration and treatment ( $P$. periphylla homogenate, autoclaved $P$. periphylla homogenate and seawater).

Impact of Periphylla periphylla size: Differently sized $P$. periphylla may possibly contain different compounds or amounts of growth suppressants per unit volume. We therefore examined the effect of $P$. periphylla size on bacterial growth by exposing 2 bacterial strains to equal volumetric amounts of homogenate, made from each of 10 whole animals ranging in size from 5.9 to $900 \mathrm{~g}$ wet weight (Table 2). In this experiment, separate $P$. periphylla size-specific and treatment-specific blanks without bacteria were used to ensure that the bacterial growth signal, measured as OD, was independent of potential differences in optical properties between homogenates.

Impact of Periphylla periphylla body parts: While larger metazoans are generally sensitive to nematocyst toxin, we hypothesized that microbes may react to components present in the body tissue of the jellyfish, rather than to the nematocyst toxins per se. We examined this by exposing 2 bacterial isolates to equal volumetric amounts of homogenate made from either tentacles, top dome (i.e. the ectoderm and mesoglea above the coronal furrow in the exumbrella), body (i.e. all other tissue except the tentacles), tentacles, and whole animals (Table 2). As the compounds affecting bacterial growth were unknown, no corrections were made for potential differences in tissue structure, chemical composition or density. Tissue specific blanks were used to ensure that the bacterial growth signal, measured as OD, was independent of any differences in optical properties between homogenates from different tissues.

Statistical analyses. Statistical analyses were done using the software $\mathrm{R}$ ( $\mathrm{R}$ development Core Team 2005) and the package nlme (Pinheiro et al. 2005), unless otherwise noted. Details pertaining to statistical analyses are incorporated in the results.

\section{RESULTS}

\section{In situ degradation experiment}

We analyzed the degradation data by fitting exponential decay models to the wet weights as a function of time for each size group. The overall fits, as well as the coefficients were statistically significant for all sizes, with $b$-coefficients of 0.67 to $1.12 \mathrm{~d}^{-1}$ (Fig. 1A). We tested for differences between size groups in the exponentially decreasing part of the degradation curves with a homogeneity-of-slopes-model on the natural logarithms of wet weights. This analysis included the first 2 time-points for the small size group and the first 5 time-points for the other size groups. The slopes of the size groups were different as indicated by the interaction between initial size and time $(\mathrm{p}<0.000001)$. A Tukey Honest Significant Difference (Tukey HSD) test revealed that all groups differed from one another (all p-values $\leq 0.0008$ ). For the 3 size groups placed at a common temperature, turnover scaled with initial weight to a power of $-0.43 \pm 0.09$, which is similar to the hypothesized $1 / 3$ from surface to volume relationships (Fig. 1B), i.e. for similarly shaped objects with a linear dimension $r$ :

$$
\frac{\text { surface }}{\text { volume }} \propto \frac{r^{2}}{r^{3}}=\frac{1}{r} \propto \frac{1}{\text { weight }^{1 / 3}}
$$

The C:N ratio of the decaying jellyfish increased in the beginning of the experiment and then decreased (Fig. 1C,D). The fit (not shown) of a second order polynomial confirmed this pattern; it gave a parabola with a maximum $\mathrm{C}: \mathrm{N}$ at $3.4 \mathrm{~d}$ and a significant negative coefficient of the quadratic term ( $p=0.0055)$. 

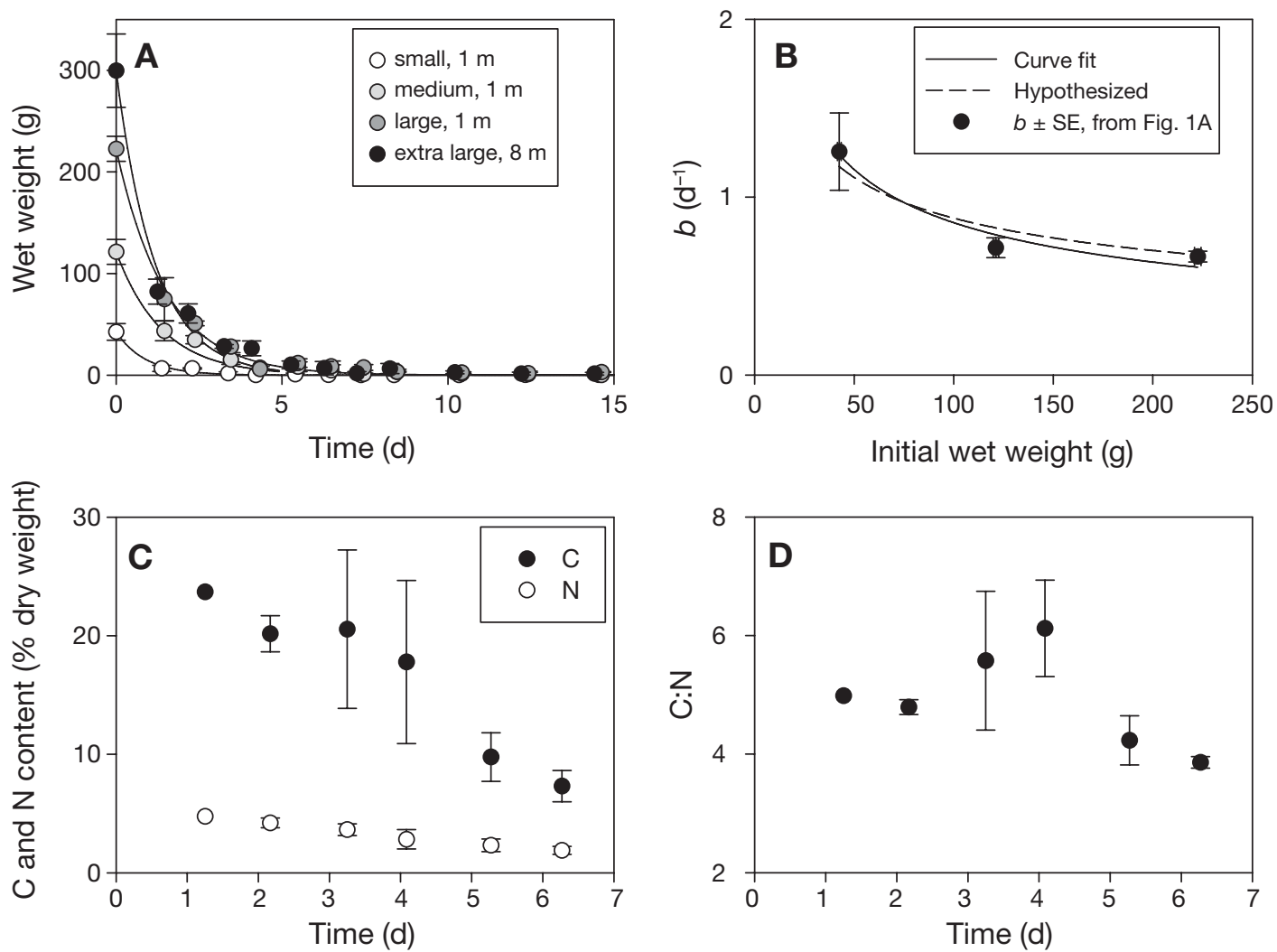

Fig. 1. Periphylla periphylla. In situ degradation experiment. (A) P. periphylla degradation. Data are mean \pm SD. The curve fits are exponential decay models to the original non-averaged data; $y=a \mathrm{e}^{-b x}$, where $y$ is wet weight $(g)$ and $x$ is time. Curve fits with $\mathrm{SE}$ of coefficients in parentheses for the different size categories are: small $y=42.08( \pm 0.91) \mathrm{e}^{-1.12( \pm 0.22) x}, \mathrm{R}^{2}=0.93, \mathrm{n}=82 ;$ medium $y=121.2( \pm 1.4) \mathrm{e}^{-0.716( \pm 0.056) x}, \mathrm{R}^{2}=0.98, \mathrm{n}=84 ;$ large $y=222.6( \pm 1.6) \mathrm{e}^{-0.666( \pm 0.031) x}, \mathrm{R}^{2}=0.99, \mathrm{n}=80 ;$ extra large $y=299.3( \pm 4.1)$ $\mathrm{e}^{-0.844( \pm 0.031) x}, \mathrm{R}^{2}=0.97, \mathrm{n}=84$. All coefficients and curve fits are statistically significant with $\mathrm{p}$-values $<0.05$. Temperature during the first week was $10.1 \pm 0.5^{\circ} \mathrm{C}$ at $1 \mathrm{~m}$ and $12.5 \pm 0.1^{\circ} \mathrm{C}$ at $8 \mathrm{~m}$. (B) Rate coefficients as a function of initial P. periphylla wet weight for the 3 size groups kept at the shallow depth. The dashed line is a power function with a forced slope of $-1 / 3$, which is that hypothesized from surface to volume ratio (see 'Results'), while the fitted solid line has a power of $\sim 0.4 \pm 0.09$. (C) Carbon and nitrogen contents as a function of time for the extra large category. Data are only shown for the first week because $95 \%$ of the initial wet weight was degraded during the first $5 \mathrm{~d}$. (D) C:N ratios from individual data points reported in (C)

\section{Shipboard experiments: development of microbes around dead Periphylla periphylla}

We hypothesized that the rapid breakdown observed in the in situ experiment in Raunefjorden was due mainly to microbial colonization and a large release of dissolved organic matter. This was further examined in the shipboard experiment where we monitored bacterial growth, carbon and nutrient release around dead Periphylla periphylla.

TOC and nutrients in the Periphylla periphylla enriched containers increased with time (Fig. 2C,D). We modeled the TOC data by linear regression with individual components in the slope, allowing for different variations in the 2 groups. The fixed effects of the slope differed between the enriched containers and the non-enriched controls ( $\mathrm{p}<0.0001)$. A Mann-Whitney test confirmed that $\mathrm{PO}_{4}{ }^{3-}(\mathrm{p}=0.020)$ and $\mathrm{NH}_{4}{ }^{+}(\mathrm{p}=$ $0.020)$ concentrations were higher in the enriched con- tainers than in the controls, while $\mathrm{NO}_{2}{ }^{-}+\mathrm{NO}_{3}{ }^{-}$concentrations were not $(p=0.12)$.

Despite the tremendous amount of released carbon and nutrients, bacteria showed strong bimodality in their response to the jellyfish enrichment. Growth was high in some experimental chambers, while negative in others (Fig. 2A,B). Growth rates varied between -0.2 and $7.0 \mathrm{~d}^{-1}$ during the first $40 \mathrm{~h}$. The pattern was repeated in both experiments, and the controls were generally stable in all parameters measured, indicating a true experimental signal (Fig. 2). To statistically confirm this visual impression, we regressed the logarithms of the bacterial abundances on the time for each individual container separately. A Siegel-Tukey test (Lehman 1975) applied the individual slopes revealed a difference in the spreads between the Periphylla periphylla enriched group and the controls for both small $(p=0.005)$ and large $(p=0.024)$ containers (Fig. 2A,B). 

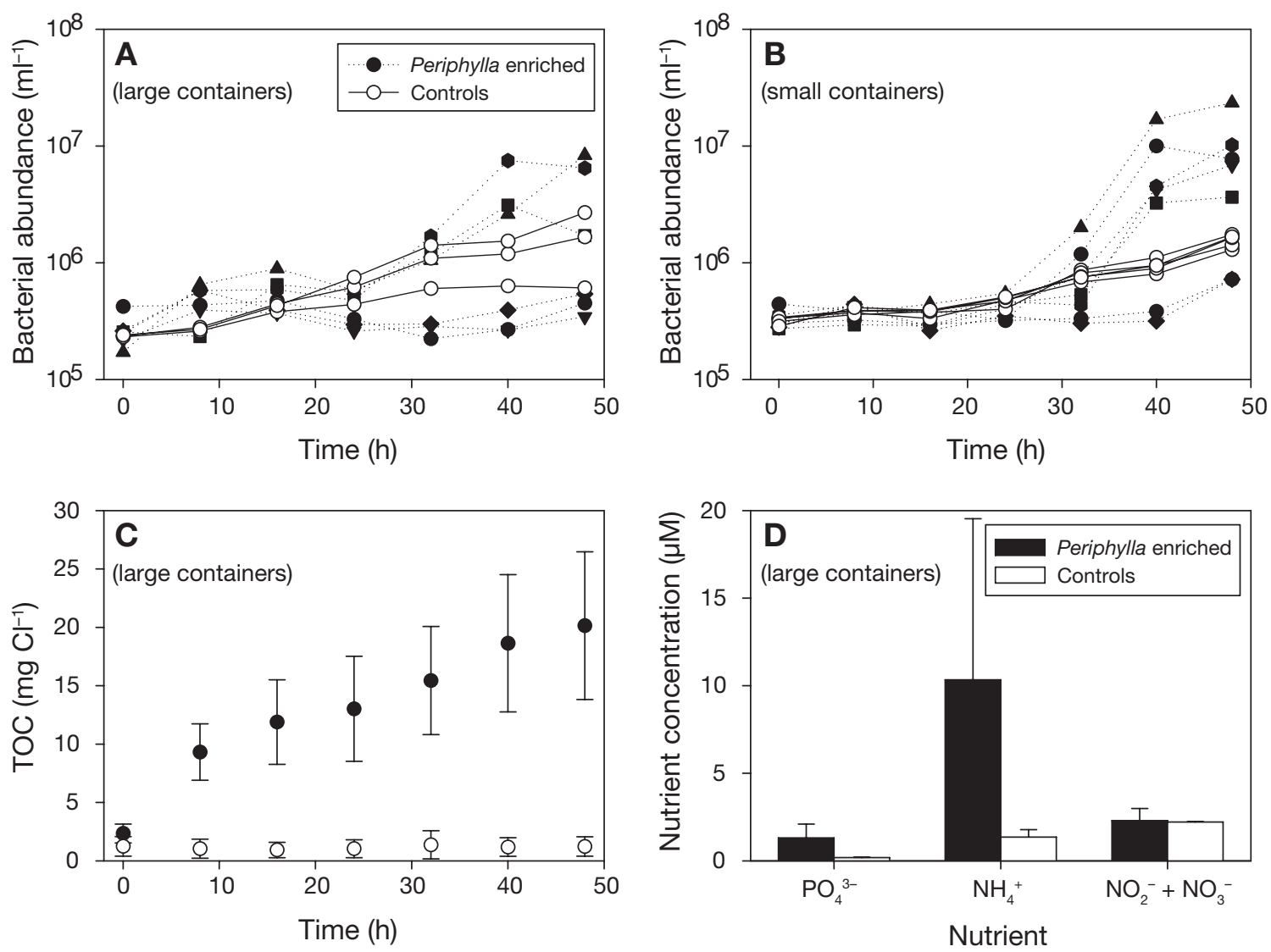

Fig. 2. Shipboard incubation experiment with natural bacterial assemblages from Lurefjorden. Development of bacterial concentrations in the incubation experiments in (A) large and (B) small containers. Symbol types represent individual containers, while fill represents treatment; black: containers with added Periphylla periphylla substrate; white: control containers without added substrate. (C) Mean ( $\pm \mathrm{SD}$ ) total organic carbon (TOC) content as a function of time in the large containers. Fills as in (A,B).

(D) Mean (+ SD) nutrient concentrations in the large containers at the termination of the experiment

We examined bacterial morphology in the samples (Fig. 3). The bacterial assemblage used as inoculum in the incubations, the communities growing in the control incubations, as well as the bacterial communities in incubations where a decrease in bacterial abundance was seen, consisted of a mix of different bacterial morphotypes (e.g. Fig. 3A). In contrast, incubations with pronounced bacterial growth towards the end of the experiment were dominated ( $>90 \%$ of all cells) by single morphotypes (Fig. 3B-E). These monoculturelike bacteria extensively colonized cnidocytes released from Periphylla periphylla (Fig. 3H-J). Although these morphotypes varied between incubations, they generally consisted of large rod-shaped cells. In one incubation, only small coccoid cells were seen (Fig. 3B). No flagellates were observed, indicating that flagellate grazing during incubations was insignificant.

When overlaying the data in Fig. 2A,B with the bacterial morphology information (Fig. 3) and correcting for Periphylla periphylla sizes and water volumes used, an interaction between cell type and $P$. periphylla enrichment appears (Fig. 4A). Linear regressions revealed a biomass increase of the monoculture-like cells $(p=0.0065)$ and a decrease of the other cell types $(p=0.012)$ with increasing enrichment (Fig. 4A). The slopes of these lines differed $(p=0.0065)$. In this regression analysis we allowed for heteroscedasity when using the function gls of nlme (Pinheiro et al. 2005). The bacterial production measured in the large containers partially mirrored this picture (Fig. 4B). However, the large individual variation with time prevented adequate statistical analysis.

\section{Growth of bacterial isolates in response to Periphylla periphylla}

\section{Screening}

We hypothesized that inhibiting compounds in Periphylla periphylla would be destroyed by autoclavation. Thus, a lower OD in P. periphylla than in autoclaved 

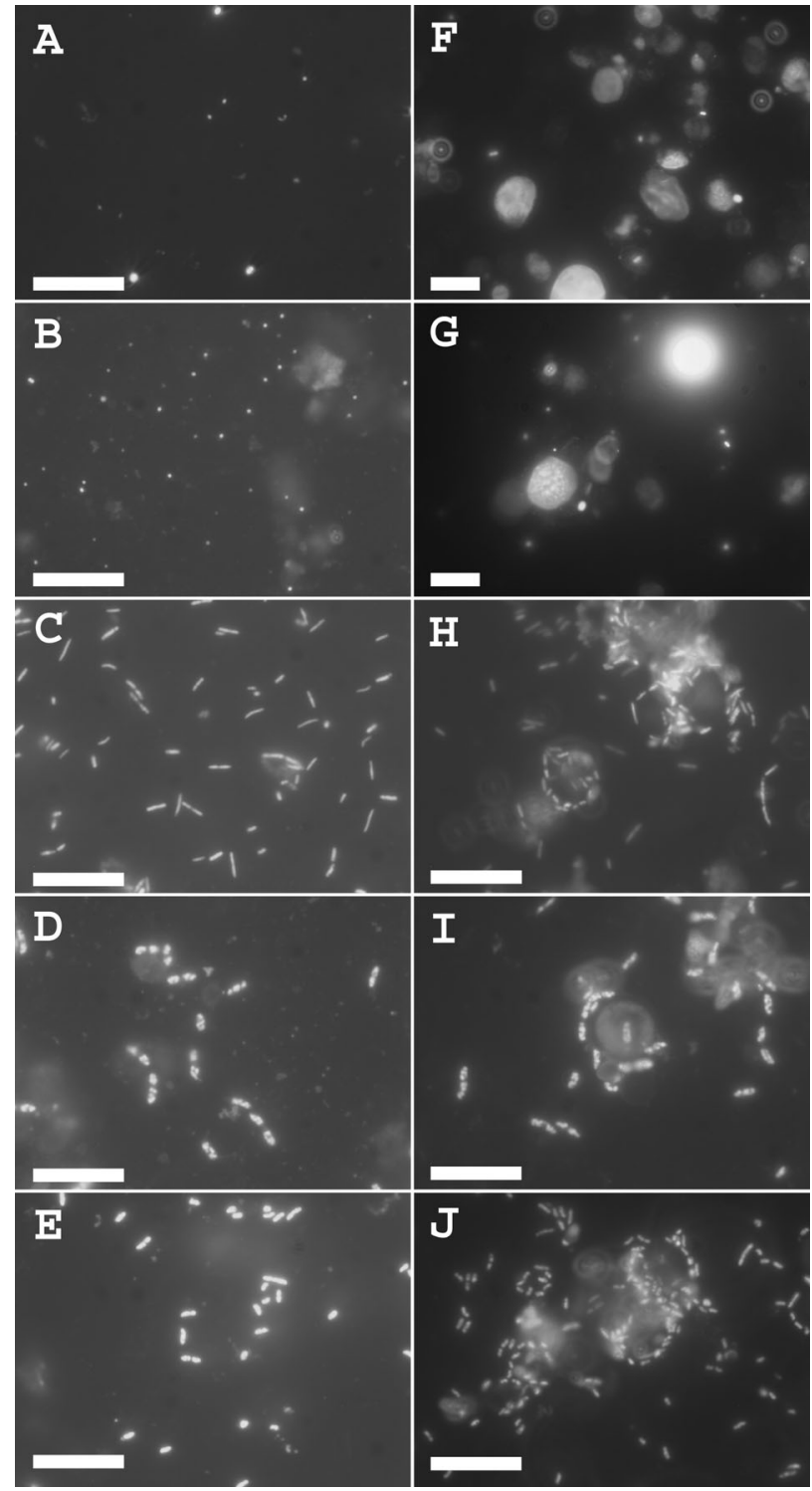

Fig. 3. Bacterial development in the shipboard incubation experiment. Scale bars $=10 \mu \mathrm{m}$. (A) Inoculum showing different cell morphologies at $t=0 \mathrm{~h}$. (B-E) The different morphotypes, with monoculture-like appearance contributing $>90 \%$ dominance at $t=40 \mathrm{~h}$. (F-J) Periphylla periphylla cnidocytes and bacterial colonization of these. (F-G) Cells from P. periphylla at $t=8 \mathrm{~h}$. $(\mathrm{H}-\mathrm{J})$ Colonization by bacterial morphotypes shown in (C-E) at $t=40 \mathrm{~h}$

$P$. periphylla treatments would suggest a net inhibitory effect of the $P$. periphylla, while a higher OD in autoclaved or raw $P$. periphylla than in the seawater controls would suggest a net enrichment. The screening experiment confirmed that different bacteria respond differently to $P$. periphylla (Fig. 5). We analyzed the OD curves as a function of time, accounting for the longitudinal data of the individual test tubes:
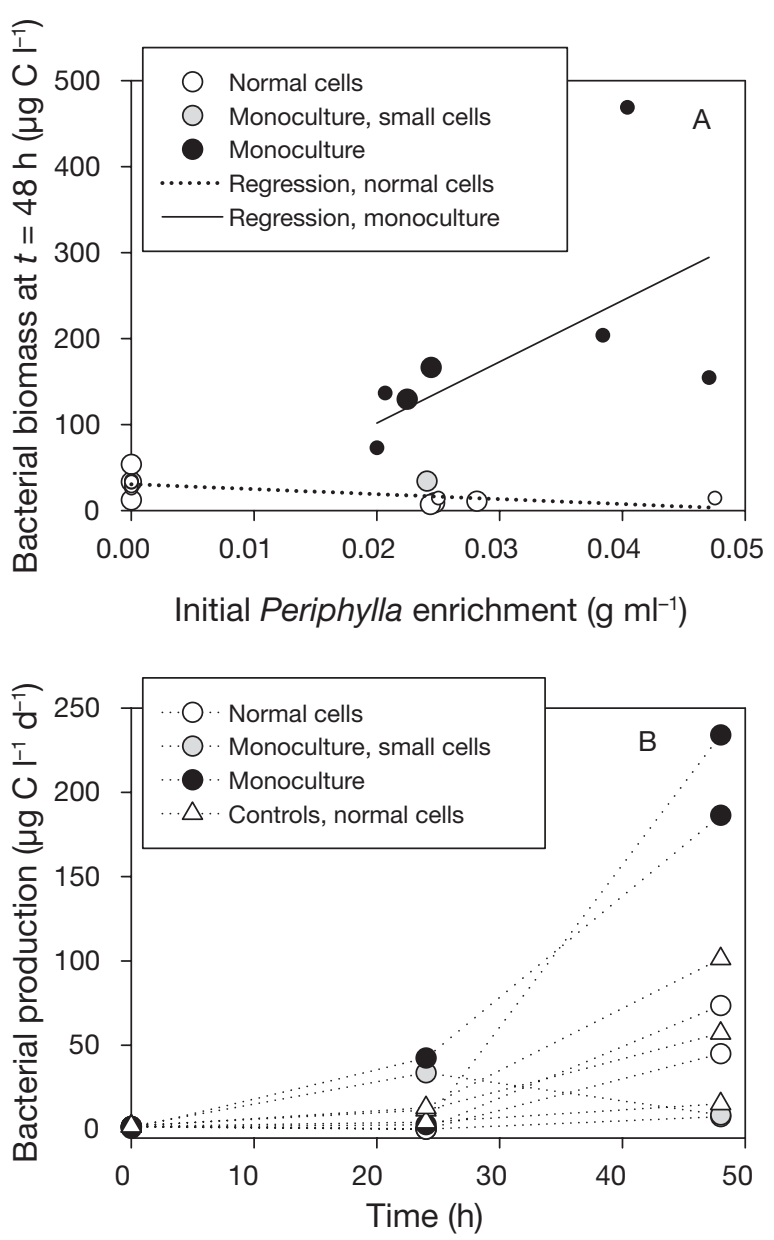

Fig. 4. Bacterial (A) biomass and (B) production in the shipboard incubation experiment. The cell morphotypes dominating in the microscopical counts (cf. Fig. 3, see also 'Results') are indicated by fills. 'Normal' cells imply a variety of cell types similar to that in Fig. 3A, and 'monoculture', implies cell morphologies similar to that in Fig. 3B-E. (A) Bacterial biomass as a function of initial enrichment. Large circles indicate the large container experiment (cf. Fig. 2A) and small circles the small container experiment (cf. Fig. 2B). Biomass at $t=48 \mathrm{~h}$ was calculated by assuming $20 \mathrm{fg} \mathrm{C}$ bacterium $^{-1}$ (Lee \& Fuhrman 1987). (B) Bacterial production as a function of time in the large container incubations as measured by thymidine incorporation. Dotted lines connect individual containers

$$
\begin{aligned}
y_{i j}= & \left(\beta_{0}+b_{0 i}\right)+\left(\beta_{1}+\gamma_{1} P_{i}+\delta_{1} C_{i}+b_{1 i}\right) t_{i j} \\
& +\left(\beta_{2}+\gamma_{2} P_{i}+\delta_{2} C_{i}\right) t_{i j}^{2}+\varepsilon_{i j}
\end{aligned}
$$

Here, $y_{i j}$ denotes the OD of test tube $i$ at the $j$ 'th timepoint $t_{i j}$. Greek letters denote fixed effects, lower case Roman letters denote tube specific random effects and $\varepsilon_{i j}$ denotes the homoscedastic normal errors. $P_{i}$ and $C_{i}$ are binary variables taking the value 1 if test tube $i$ contains raw Periphylla periphylla (for $P_{i}$ ) or seawater (for $C_{i}$ ), and 0 otherwise. Thus, $\beta_{1}$ and $\beta_{2}$ are inter- 

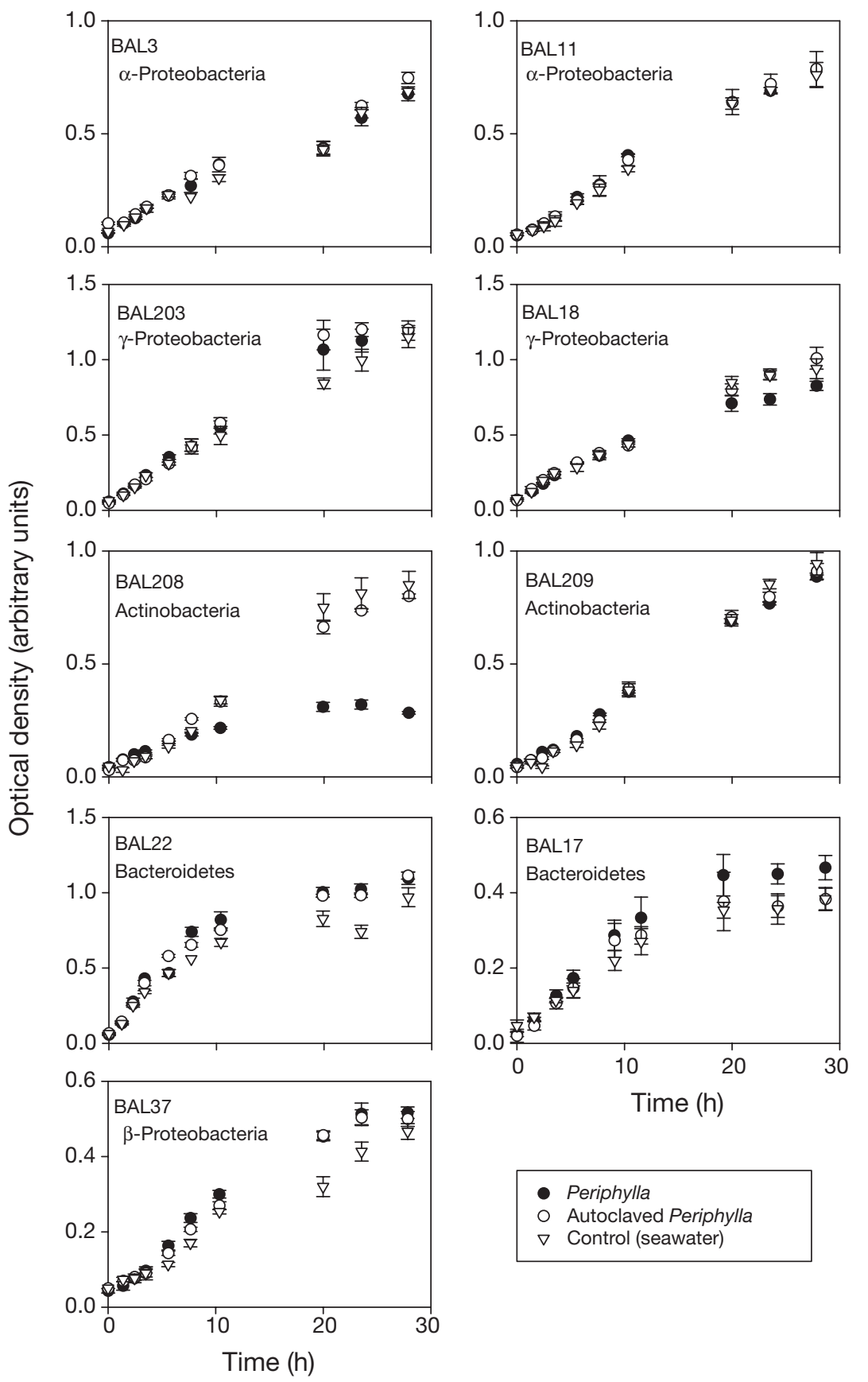

- Periphylla

- Autoclaved Periphylla

$\nabla$ Control (seawater)

$\left(\delta_{2}-\gamma_{2}\right)$ show how much larger the seawater controls are than the P. periphylla treatments. The linear and quadratic terms represent the initial growth and the slowing down of the growth for larger time values, respectively.

Periphylla periphylla had no effect on the $2 \alpha$-Proteobacteria (BAL3 and BAL11) (Fig. 5, Table 3). The $\beta$-Proteobacterium (BAL37) grew better on raw and autoclaved $P$. periphylla relative to the seawater controls, while there were no differences between raw and autoclaved $P$. periphylla (Fig. 5, Table 3). Similarly, BAL17 (Bacteroidetes) grew slower in the seawater treatment than in the $P$. periphylla treatments, but growth did not slow down as fast as in the $P$. periphylla treatments (Fig. 5, Table 3). The other Bacteroidetes isolate (BAL22) also grew better in the $P$. periphylla treatment than in the seawater control, while there were no differences between the raw and autoclaved $P$. periphylla treatments (Fig. 5, Table 3). P. periphylla affected the Actinobacteria (BAL208, BAL209) negatively. For BAL208, the initial growth was lower in the P. periphylla treatment than in the other treatments and growth also leveled off most rapidly in the $P$. periphylla treatment (Fig 5, Table 3). For BAL209 the growth curves were so linear that the quadratic term could be dropped. Doing so revealed that initial (linear) growth was lowest in the $P$. periphylla treatment (Fig. 5, Table 3). For BAL18 $(\gamma$-Proteobacteria) initial growth did not differ between treatments; however, the P. periphylla treatment slowed down most rapidly (Fig. 5, Table 3). BAL3, BAL18, and BAL208 were selected for further experiments.

\section{Concentration experiment}

While BAL208 responded negatively to increasing Periphylla periphylla conpreted as the average contribution to the linear and quadratic terms, respectively, for autoclaved P. periphylla and the corresponding $\gamma$ 's and $\delta$ 's show how much $P$. periphylla and seawater deviate from the autoclaved $P$. periphylla. The differences $\left(\delta_{1}-\gamma_{1}\right)$ and centrations, the signal was less obvious for BAL3 and BAL18 (Fig. 6). To quantify the signal as a function of homogenate addition we adjusted Eq. 1 to let coefficients depend linearly on $P$. periphylla concentration ( $x$, dimensionless): 
Table 3. Results from statistical analysis (Eq. 1) of screening experiment (Fig. 5). Estimated coefficients and their respective individual p-value in parentheses. Bold indicates statistical significance (i.e. p < 0.05). For BAL209 the growth curves were so linear that the quadratic term could be dropped. The lower of the 2 BAL209 lines reports the analysis without the quadratic term

\begin{tabular}{|c|c|c|c|c|c|c|}
\hline Isolate & $\begin{array}{c}\gamma_{1} \\
\text { Periphylla vs. } \\
\text { Autoclaved }\end{array}$ & $\begin{array}{c}\delta_{1} \\
\text { Seawater vs. } \\
\text { Autoclaved }\end{array}$ & $\begin{array}{c}\delta_{1}-\gamma_{1} \\
\text { Seawater vs. } \\
\text { Periphylla }\end{array}$ & $\begin{array}{c}\gamma_{2} \\
\text { Periphylla vs. } \\
\text { Autoclaved }\end{array}$ & $\begin{array}{c}\delta_{2} \\
\text { Seawater vs. } \\
\text { Autoclaved }\end{array}$ & $\begin{array}{c}\delta_{2}-\gamma_{2} \\
\text { Seawater vs. } \\
\text { Periphylla }\end{array}$ \\
\hline $\begin{array}{l}\text { BAL3 } \\
\text { ( } \alpha \text {-Proteobacteria) }\end{array}$ & $\begin{array}{c}0.0050 \\
(p=0.27)\end{array}$ & $\begin{array}{l}-0.0023 \\
(p=0.63)\end{array}$ & $\begin{array}{l}-0.0073 \\
(p=0.12)\end{array}$ & $\begin{array}{l}-0.0023 \\
(p=0.15)\end{array}$ & $\begin{array}{l}0.000053 \\
(p=0.75)\end{array}$ & $\begin{array}{c}0.00028 \\
(p=0.87)\end{array}$ \\
\hline BAL11 & 0.0021 & -0.0029 & -0.0050 & -0.00099 & 0.00081 & 0.00018 \\
\hline ( $\alpha$-Proteobacteria) & $(p=0.53$ & $(p=0.34)$ & $(\mathrm{p}=0.14)$ & $(\mathrm{p}=0.39)$ & $(p=0.43)$ & $(p=0.12)$ \\
\hline BAL37 & 0.0039 & -0.0107 & -0.015 & -0.00013 & 0.00027 & 0.00040 \\
\hline ( $\beta$-Proteobacteria) & $(p=0.14)$ & $(p=0.0001)$ & $(p=0.0001)$ & $(p=0.17)$ & $(p=0.0043)$ & $(p=0.00001)$ \\
\hline BAL18 & 0.0044 & 0.0056 & 0.00115 & -0.00040 & -0.00023 & 0.00017 \\
\hline ( $\gamma$-Proteobacteria) & $(p=0.25)$ & $(p=0.15)$ & $(p=0.76)$ & $(p=0.0037)$ & $(p=0.091)$ & $(p=0.205)$ \\
\hline BAL203 & -0.0076 & -0.023 & -0.015 & 0.00017 & 0.00055 & 0.00037 \\
\hline ( $\gamma$-Proteobacteria) & $(p=0.26)$ & $(p=0.0006)$ & $(p=0.0190)$ & $(\mathrm{p}=0.42)$ & $(p=0.0135)$ & $(p=0.088)$ \\
\hline BAL17 & 0.0032 & -0.0077 & -0.011 & -0.000008 & 0.00024 & 0.00025 \\
\hline (Bacteroidetes) & $(p=0.24)$ & $(p=0.0058)$ & $(p=0.0002)$ & $(p=0.92)$ & $(p=0.0076)$ & $(p=0.0058)$ \\
\hline BAL22 & 0.0089 & -0.015 & -0.0242 & -0.0030 & 0.00032 & 0.00062 \\
\hline (Bacteroidetes) & $(p=0.25)$ & $(p=0.051)$ & $(p=0.0025)$ & $(p=0.28)$ & $(p=0.25)$ & $(p=0.027)$ \\
\hline BAL208 & -0.012 & -0.0016 & -0.013 & -0.00031 & 0.000072 & 0.00038 \\
\hline (Actinobacteria) & $(p=0.0061)$ & $(p=0.070)$ & $(p=0.0020)$ & $(p=0.042)$ & $(p=0.63)$ & $(p=0.0127)$ \\
\hline BAL209 & -0.0011 & -0.0021 & -0.0010 & -0.000023 & 0.00015 & 0.00017 \\
\hline (Actinobacteria) & $(p=0.77)$ & $(p=0.56)$ & $(p=0.78)$ & $(p=0.86)$ & $(p=0.26)$ & $(p=0.19)$ \\
\hline BAL209 & -0.0017 & 0.0019 & 0.0036 & & & \\
\hline (Actinobacteria) & $(p=0.048)$ & $(p=0.024)$ & $(p=0.001)$ & & & \\
\hline
\end{tabular}

$$
\begin{aligned}
y_{i j}= & \left(\beta_{0}+b_{0 i}\right)+\left[\beta_{1}+\left(\delta_{1}+\gamma_{1} P_{i}\right) x_{i j}+b_{1 i}\right] t_{i j} \\
& +\left[\beta_{2}+\left(\delta_{2}+\gamma_{2} P_{i}\right) x_{i j}\right] t_{i j}^{2}+\varepsilon_{i j}
\end{aligned}
$$

Eq. 2 is the model that gave the lowest value for the BIC criterion among different similar choices (see Pinheiro et al. 2005). Here, the variables have the same meaning as in Eq. 1, and $x_{i j}$ denotes the Periphylla periphylla concentration at the $j$ 'th time point $t_{i j}$. The coefficients $\gamma_{1}$ and $\gamma_{2}$ represent the average difference for the concentration dependence of the coefficients between the $P$. periphylla and the autoclaved $P$. periphylla treatments.

For BAL3 the $\delta_{1}$ and $\delta_{2}$ do not differ from 0 (Table 4 ) implying that OD for the autoclaved Periphylla periphylla treatment was independent of concentration. There was, however, an effect of the raw P. periphylla treatment as $\gamma_{1}>0$ and $\gamma_{2}<0$ (Table 4). Thus, for small time values the $P$. periphylla treatment grew faster than the autoclaved $P$. periphylla treatment. As time increases, the quadratic term becomes more important, and the $P$. periphylla curve slows down faster than the autoclaved $P$. periphylla curve. This effect increases slightly with increasing concentration (Fig. 6, Table 4).

For BAL18, neither $\gamma_{1}$ nor $\gamma_{2}$ differ from 0 indicating that there were no differences between the 2 treatments (Table 4). However, because $\delta_{1}>0$ and $\delta_{2}<0$ (Table 4) small concentrations of both raw and autoclaved Periphylla periphylla enhance OD, while large concentrations suppress OD.
For BAL208, $\delta_{1}>0$, while $\delta_{2}$ does not differ from 0 (Table 4). This implies an increase in OD with increasing concentrations for the autoclaved Periphylla periphylla treatment. While $\gamma_{1}$ does not differ from $0, \gamma_{2}<0$ (Table 4). This means that the OD-curves start out equal, but for larger time values the $P$. periphylla curve turns downwards away from the autoclaved P. periphylla curve. This effect increases with increasing concentration (Table 4). We note that although the qualitative effect is similar in the $P$. periphylla treatment for BAL3 and BAL208, this effect is quantitatively much stronger on BAL208 than on BAL3; i.e. $\gamma_{2(B A L 208)} /$ $\gamma_{2(B A L 3)} \approx 5$ (Table 4).

\section{Impact of Periphylla periphylla size}

We examined if Periphylla periphylla of various sizes suppress bacterial growth differently by exposing bacteria to the same volumetric concentration of homogenates made from $P$. periphylla of widely different sizes $\left(x_{i}\right)$ (Fig. 7). Optical density $\left(y_{i}\right)$ was measured after $\sim 19 \mathrm{~h}$. We fitted the non-linear model

$$
y_{i}=\beta_{0}+\beta_{1} \exp \left(-x_{i} / \theta\right)+\varepsilon_{i}
$$

separately for the raw and autoclaved $P$. periphylla treatments by the package nls of R. The errors $\varepsilon_{i}$ are assumed to be independently normally distributed variables with the same variance. 


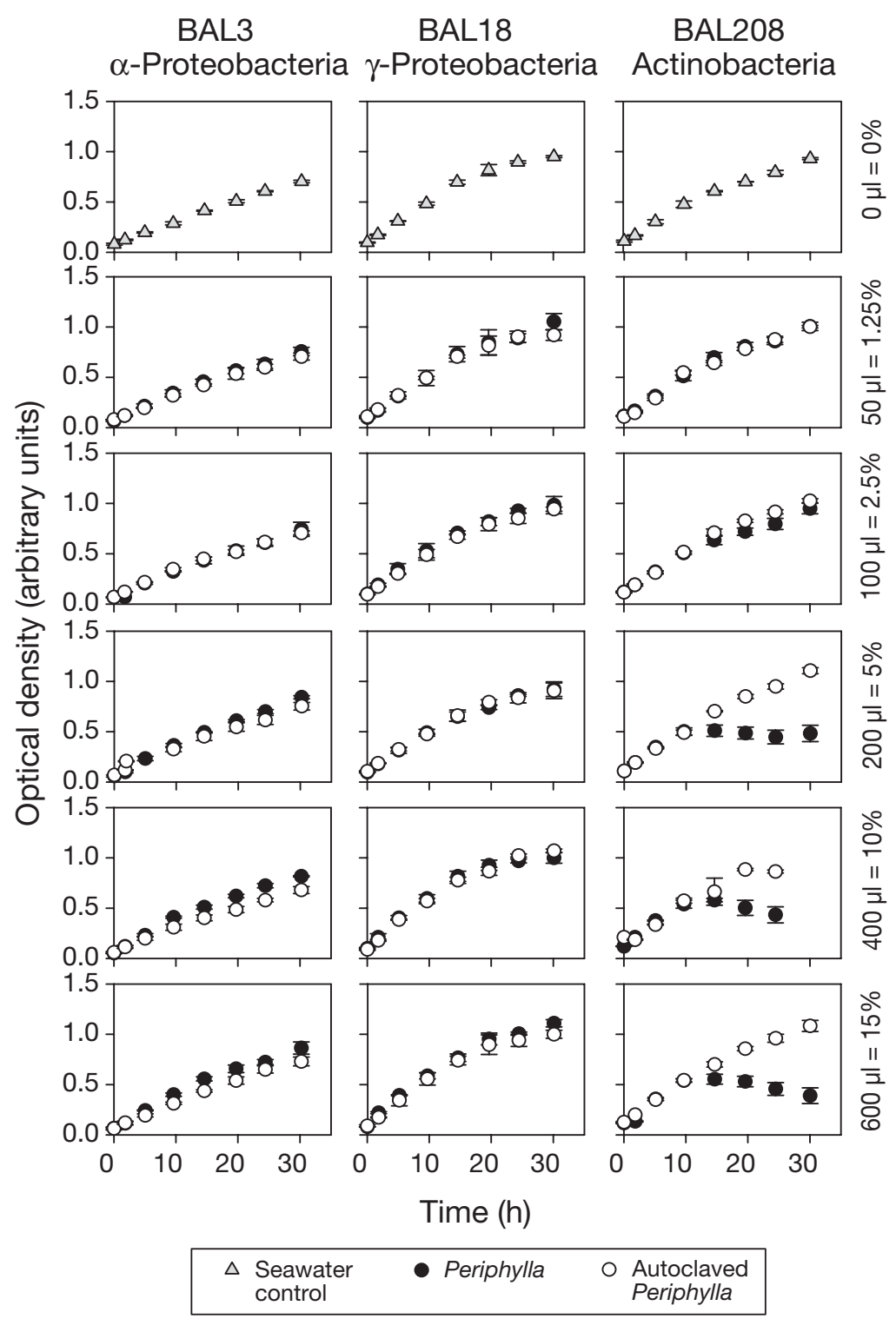

Fig. 6. Bacterial growth as a function of Periphylla periphylla homogenate concentration for 3 bacterial isolates. Each panel represents data of bacterial abundance (optical density) as a function of time for a given isolate and $P$. periphylla addition. The isolates are indicated by the column names and the volume of $P$. periphylla homogenate used at the right of each panel row.

Data are mean $\pm \mathrm{SD}$
For the Periphylla periphylla treatment in BAL208 $\beta_{1}>0(p<0.0001)$, indicating a decreased bacterial growth when exposed to homogenized P. periphylla of increasing size. In contrast, for the $P$. periphylla treatment in BAL18 $\beta_{1}<0(\mathrm{p}=0.031)$, indicating a weak increase in OD with increasing $P$. periphylla size. For autoclaved $P$. periphylla $\beta_{1}>0$ for both BAL18 ( $p=0.003$ ) and BAL208. In the latter case we are unable to report a p-value due to problems with convergence in the nls package. However, fitting with the optim package in $\mathrm{R}$ also gives a positive value, but it does not provide a p-value. In accordance with the visual impression of the figures, the asymptotic levels of the 2 treatments, that is the values for large $P$. periphylla, differ for BAL208 $(\mathrm{p}<0.000001)$ while not for BAL18 $(\mathrm{p}=$ $0.58)$.

\section{Impact of Periphylla periphylla body parts}

Different tissues of Periphylla periphylla yielded different responses (Fig. 8). For BAL18, a 2-way ANOVA revealed an effect of body part $(\mathrm{p}<$ $0.00001)$, no effect of $P$. periphylla treatment $(p=0.49)$ and no interaction between treatment and body part $(\mathrm{p}=$ 0.78). A closer examination employing Tukey's HSD method (TukeyHSD in R) and including the control group 'seawater' showed that the 'top dome' falls below and the other body parts above the seawater control, but only the 'top dome' stands out from the others (Table 5).

For BAL208, the 2-way ANOVA showed effects of body part, treatment

Table 4. Results from statistical analysis (Eq. 2) of concentration experiment (Fig. 6). Estimated coefficients and their respective individual p-values in parentheses. Bold indicates statistical significance (i.e. $\mathrm{p}<0.05$ )

\begin{tabular}{|c|c|c|c|c|c|c|}
\hline Isolate & $\beta_{1}$ & $\delta_{1}$ & $\gamma_{1}$ & $\beta_{2}$ & $\delta_{2}$ & $\gamma_{2}$ \\
\hline $\begin{array}{l}\text { BAL3 } \\
\text { ( } \alpha \text {-Proteobacteria) }\end{array}$ & $\begin{array}{c}0.027 \\
(p<0.0001)\end{array}$ & $\begin{array}{l}0.0000022 \\
(p=0.28)\end{array}$ & $\begin{array}{c}0.000017 \\
(p<0.0001)\end{array}$ & $\begin{array}{c}-0.00019 \\
(p<0.0001)\end{array}$ & $\begin{array}{c}-0.00000006 \\
(p=0.35)\end{array}$ & $\begin{array}{c}-0.00000031 \\
(p=0.0001)\end{array}$ \\
\hline $\begin{array}{l}\text { BAL18 } \\
\text { ( } \gamma \text {-Proteobacteria) }\end{array}$ & $\begin{array}{c}0.050 \\
(p<0.0001)\end{array}$ & $\begin{array}{c}0.000014 \\
(p=0.0001)\end{array}$ & $\begin{array}{l}0.0000073 \\
(p=0.056)\end{array}$ & $\begin{array}{c}-0.00071 \\
(p<0.0001)\end{array}$ & $\begin{array}{c}-0.00000032 \\
(p=0.0024)\end{array}$ & $\begin{array}{c}-0.00000018 \\
(p=0.12)\end{array}$ \\
\hline $\begin{array}{l}\text { BAL208 } \\
\text { (Actinobacteria) }\end{array}$ & $\begin{array}{c}0.041 \\
(p<0.0001)\end{array}$ & $\begin{array}{c}0.000017 \\
(p<0.0001)\end{array}$ & $\begin{array}{c}-0.00000050 \\
(p=0.90)\end{array}$ & $\begin{array}{c}-0.00047 \\
(p=0.0001)\end{array}$ & $\begin{array}{c}-0.00000024 \\
(\mathrm{p}=0.075)\end{array}$ & $\begin{array}{l}-0.0000016 \\
(\mathrm{p}<0.0001)\end{array}$ \\
\hline
\end{tabular}




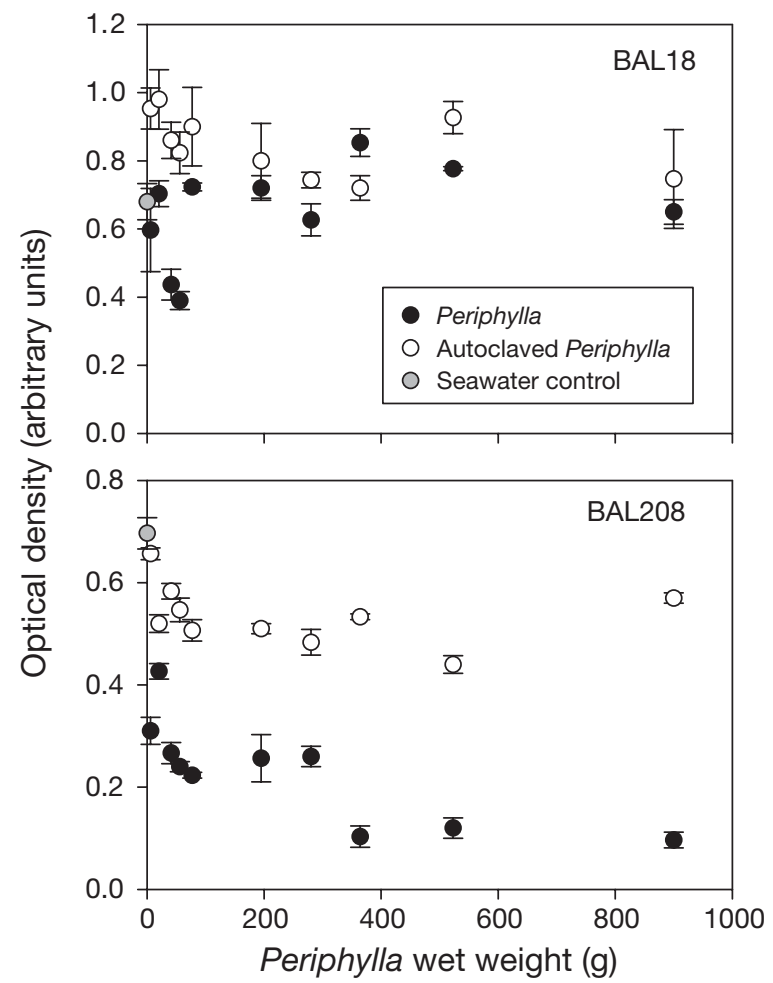

Fig. 7. Response of 2 isolates to homogenate made from differently sized Periphylla periphylla. Data are reported as optical density at $t=19 \mathrm{~h}$ and are mean $\pm \mathrm{SD}$. The isolate names are indicated in the panels

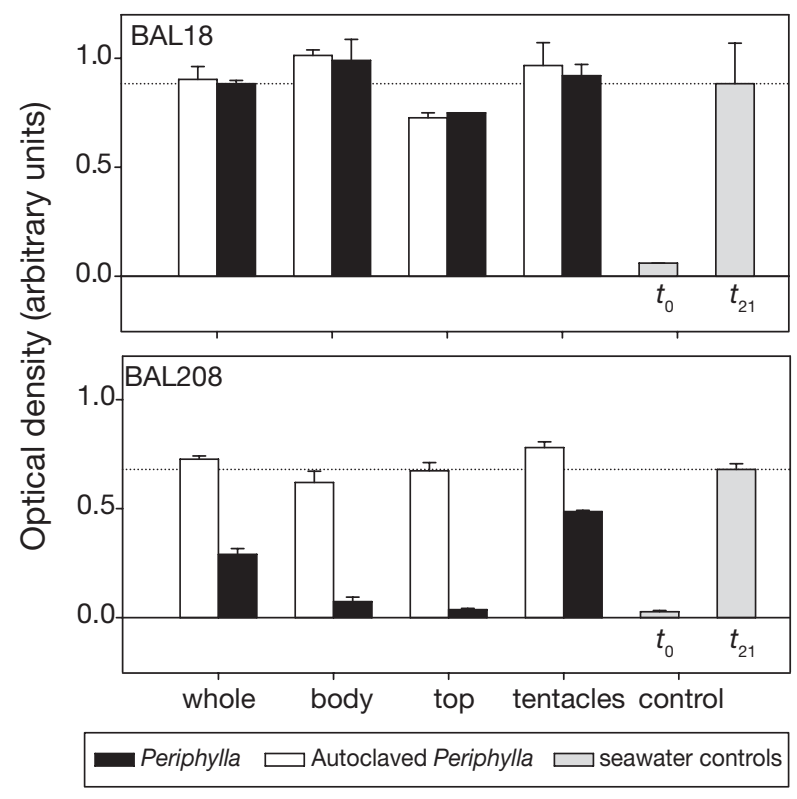

Fig. 8. Optical density at $t=21 \mathrm{~h}$ for 2 bacterial isolates exposed to homogenate made from different Periphylla periphylla tissues. The seawater control is given also for $t=0$ and equals the start concentration for all treatments. The isolate names are indicated in the panels. BAL18 was also observed at $t=30 \mathrm{~h}$ with similar results (not shown) and an interaction between body part and treatment (all p-values <0.000001). Tukey's HSD method generally revealed that the autoclaved treatments did not differ from the seawater control, while OD in the Periphylla periphylla treatments were lower than in the controls (Table 6). The $P$. periphylla treatments 'body' and 'top dome' did not differ from one another (Fig. 8). Apparently, the growth suppressing compounds are strongest or more concentrated in the top dome and weakest in the tentacles (Fig. 8, Table 6). Most of this effect is destroyed in the autoclavation.

\section{DISCUSSION}

\section{Degradation of jellyfish}

The shipboard and laboratory experiments suggested that only some bacterial species thrive around dead Periphylla periphylla, while others are inhibited by this jellyfish (Figs. 2 to 5). Despite this, pelagic turnover of jellyfish is rapid (Fig. 1). If correcting for temperature differences, assuming a $\mathrm{Q}_{10}$ of 2.3 (Bidle et al. 2002), the decay times of 4.1 to $7 \mathrm{~d}\left(10\right.$ to $\left.12^{\circ} \mathrm{C}\right)$ observed here (Fig. 1) are faster than those measured on Aurelia aurita immobilized in nets in large tanks with Swedish fjord water $\left(4.9 \mathrm{~d}, 15\right.$ to $17^{\circ} \mathrm{C}$, initial weight 149 to $428 \mathrm{~g}$, Hansson 1997). Assuming extensive microbial colonization and degradation of $P$. periphylla tissue, nitrogen-rich compounds would presumably be hydrolyzed faster than carbon-rich pools such as polysaccharides, analogous to degradation of marine snow (Smith et al. 1992). In accordance, the $\mathrm{C}: \mathrm{N}$ ratio increased during the first 3 to 4 days (Fig. 1D) of degradation. We did not quantify bacterial production or colonizers in the in situ experiment. When pulling up the jellyfish, clouds of motile organisms, including oncaid and harpacticoid copepods, as well as particulate matter originating from the jellyfish were visible (J. Titelman, T. Sørnes, pers. obs.). Presumably, colonizers consist of organisms such as bacteria, flagellates, ciliates and copepods, similar to those observed on marine snow (Kiørboe 2000). Ultimately, the residence time in suspension determines the contribution of dead jellyfish as a substrate for pelagic organisms. Settling rates are a function of diameter and density, both of which may be affected by differential remineralization (Berelson 2002). Inhibitory effects on microbial activity by $P$. periphylla are apparently size and tissue dependent (Figs. $7 \&$ 8), perhaps affecting residence time in the water column.

Some jellyfish regulate their buoyancy to become neutral or even positively buoyant, while others are negatively buoyant (Mills 1981, Graham et al. 2001). Live Periphylla periphylla in Lurefjorden hang motion- 
Table 5. Results from Tukey HSD test of body part experiment for BAL18. Values are Bonferroni adjusted p-values. Bold indicates significant differences. The tested groups correspond to those depicted in Fig. 8. Treatments were not considered in this analysis as the 2-way ANOVA showed no effect of treatment for this isolate

\begin{tabular}{|lccccc|}
\hline & Top & Body & Tentacles & Whole & Seawater control \\
\hline Top & - & & & & \\
Body & $\mathbf{0 . 0 0 0 0 5}$ & - & & & \\
Tentacles & $\mathbf{0 . 0 0 1 2}$ & 0.69 & - & & \\
Whole & $\mathbf{0 . 0 1 6}$ & 0.14 & 0.79 & - & - \\
Seawater & 0.093 & 0.23 & 0.80 & 0.99 & - \\
\hline
\end{tabular}

less for up to $2 \mathrm{~h}$ at mid depths (Youngbluth \& Båmstedt 2001), while they sink slowly if not pulsing when residing in the less saline surface water (Sørnes 2005). Similarly, live hydromedusae sink at rates from 0 to $\sim 1700 \mathrm{~m} \mathrm{~d}^{-1}$ in the laboratory, depending on species and condition (Mills 1981). Unfortunately, there are few published sinking rates available, and dead and live jellyfish likely sink at different rates. For comparative purposes only, abandoned houses (mean length 68 $\pm 24 \mathrm{~cm}$ ) of the large appendicularian Bathochordeaus sink at $~ 820 \mathrm{~m} \mathrm{~d}^{-1}$ (Hamner \& Robison 1992), while houses (mean diameter $=1.13 \mathrm{~mm}$ ) of the smaller Oikopleura dioica sink at $\sim 120 \mathrm{~m} \mathrm{~d}^{-1}$ (Hansen et al. 1986), and dead Aurelia aurita medusae are often found drifting at the surface (pers. obs.).

Live jellyfish release DOC at a rate of $\sim 0.012 \mathrm{mg} \mathrm{C} \mathrm{g}$ wet weight ${ }^{-1} \mathrm{~d}^{-1}$ (Aurelia aurita, in Hansson \& Norrman 1995) and may contribute substantially to the pool of TOC in jellyfish rich environments (Periphylla periphylla, in Riemann et al. 2006). In comparison dead jellyfish leak DOC to the surrounding water at a rate of $\sim 0.36 \mathrm{mg} \mathrm{C}$ g wet weight ${ }^{-1} \mathrm{~d}^{-1}$ (calculated from Fig. 2), suggesting that dead jellyfish may provide hotspots of substrate in pelagic (and benthic) environments. Rapid turnover of dead jellyfish by microbes and zooplankters (Fig. 1) may be quantitatively important for returning energy to the pelagic foodweb at times of high jellyfish abundance. However, the extent of degradation mediated by bacteria varies with jellyfish species, size and body part, as well as with the composition of the local bacterial assemblage.

\section{Periphylla periphylla as a substrate}

In Lurefjorden, the density gradients are weak below $\sim 50 \mathrm{~m}$ (Eiane et al. 1999, Riemann et al. 2006). The density of Periphylla periphylla from Lurefjorden is crudely estimated at $\sim 1.05 \pm 0.02 \mathrm{~g} \mathrm{~cm}^{-3}$ (mean $\pm \mathrm{SD}$, from wet weights and morphometrics of 15 animals), suggesting that dead $P$. periphylla would sink slowly out of the water column. Given decay coefficients of 0.67 to $1.12 \mathrm{~d}^{-1}$ (Fig. 1) a significant portion of dead jellyfish in such systems remain subject to some pelagic degradation, and the weight of dead jellyfish would be substantially reduced, of course depending on the depth at which the final travel started (cf. Fig. 1).

Table 6. Tukey HSD test of Periphylla body part experiment for BAL208. Values are Bonferroni adjusted p-values resulting from testing the groups in the vertical list against the groups in the horizontal header (all against all). Bold indicates significant differences. The tested groups correspond to those depicted in Fig. 8. Treatments are indicated in parentheses

\begin{tabular}{|c|c|c|c|c|c|c|c|c|c|}
\hline & $\begin{array}{c}\text { Top } \\
\text { (Periphylla) }\end{array}$ & $\begin{array}{c}\text { Top } \\
\text { (autoclaved) }\end{array}$ & $\begin{array}{c}\text { Body } \\
\text { (Periphylla) }\end{array}$ & $\begin{array}{c}\text { Body } \\
\text { (autoclaved) }\end{array}$ & $\begin{array}{l}\text { Tentacles } \\
\text { (Periphylla) }\end{array}$ & $\begin{array}{l}\text { Tentacles } \\
\text { (autoclaved) }\end{array}$ & $\begin{array}{c}\text { Whole } \\
\text { (Periphylla) }\end{array}$ & $\begin{array}{c}\text { Whole } \\
\text { (autoclaved) }\end{array}$ & $\begin{array}{l}\text { Seawater } \\
\text { control }\end{array}$ \\
\hline $\begin{array}{l}\text { Top } \\
\text { (Periphylla) }\end{array}$ & - & & & & & & & & \\
\hline $\begin{array}{l}\text { Top } \\
\text { (autoclaved) }\end{array}$ & $<0.00001$ & - & & & & & & & \\
\hline $\begin{array}{l}\text { Body } \\
\text { (Periphylla) }\end{array}$ & 0.786 & $<0.00001$ & - & & & & & & \\
\hline $\begin{array}{l}\text { Body } \\
\text { (autoclaved) }\end{array}$ & $<0.00001$ & 0.366 & $<0.00001$ & - & & & & & \\
\hline $\begin{array}{l}\text { Tentacles } \\
\text { (Periphylla) }\end{array}$ & $<0.00001$ & $<0.00001$ & $<0.00001$ & 0.00039 & - & & & & \\
\hline $\begin{array}{l}\text { Tentacles } \\
\text { (autoclaved) }\end{array}$ & $<0.00001$ & 0.00441 & $<0.00001$ & 0.00004 & $<0.00001$ & - & & & \\
\hline $\begin{array}{l}\text { Whole } \\
\text { (Periphylla) }\end{array}$ & $<0.00001$ & $<0.00001$ & $<0.00001$ & $<0.00001$ & $<0.00001$ & $<0.00001$ & - & & \\
\hline $\begin{array}{l}\text { Whole } \\
\text { (autoclaved) }\end{array}$ & $<0.00001$ & 0.366 & $<0.00001$ & 0.00440 & $<0.00001$ & 0.366 & $<0.00001$ & - & \\
\hline $\begin{array}{l}\text { Seawater } \\
\text { control }\end{array}$ & $<0.00001$ & 0.999 & $<0.00001$ & 0.236 & $<0.00001$ & 0.00809 & $<0.00001$ & 0.529 & - \\
\hline
\end{tabular}


Youngbluth \& Båmstedt (2001) suggested that $P$. periphylla in Lurefjorden die a natural death in absence of predators. Video observations with the ROV 'Aglantha' at the bottom of Lurefjorden and neighboring fjords (e.g. Sognefjorden, 1200 m) from 1997 to 2004 have usually revealed few dead jellyfish (J. Titelman, T. Sørnes \& U. Båmstedt pers. obs.), suggesting low mortality or that $P$. periphylla are degraded or consumed before reaching the bottom. Also, occasional observations from shallow-water bottoms $(5 \mathrm{~m})$ suggest that dead P. periphylla may rapidly attract benthic scavengers.

To examine the degradation of Periphylla periphylla, we conducted a shipboard experiment using natural bacterial assemblages from Lurefjorden. Despite tremendous carbon and nutrient release from the dead jellyfish (Fig. 2), only some bacterial morphotypes were apparently able to use this substrate while others were inhibited (Figs. 2 to 4 ). The positive response was observed as extensive growth and a monoculture-like appearance in some incubations, and as pronounced colonization of $P$. periphylla cells. In corroboration, our laboratory experiments using 9 bacterial isolates, demonstrated that homogenized P. periphylla tissue selectively inhibited several bacteria, one $\gamma$-Proteobacterium (BAL18) and 2 Actinobacteria (BAL208 and BAL209) (Fig. 5). Hence, some, but not all, bacterial species can actively degrade $P$. periphylla tissue. Therefore, the bacterial community composition may affect the role of jellyfish as trophic links in specific pelagic foodwebs.

We chose bacterial isolates from various phylogenetic groups to get an indication of whether certain groups were inhibited by Periphylla periphylla. Our finding that a $\gamma$-Proteobacterium (BAL18) and the Actinobacteria (BAL208 and BAL209) are sensitive to P. periphylla contrast with those of Long \& Azam (2001) and Grossart et al. (2004), who showed that these phylogenetic groups were the most prolific producers of antagonistic molecules and also the most resilient to them, while members of Bacteroidetes were the most sensitive to antagonistic compounds. Here, members of Bacteroidetes rather benefited from the P. periphylla homogenate in the laboratory experiments (Fig. 5). Bacteroidetes also dominated in Lurefjorden, thriving at depths with high $P$. periphylla biomass (Riemann et al. 2006). The likely functional variability of bacterial species within these broad phylogenetic groups and the unknown resemblance of inhibitory compounds produced by $P$. periphylla (this study) and by bacteria (Long \& Azam 2001, Grossart et al. 2004) make direct comparisons between these studies speculative. Still, our findings demonstrate that $P$. periphylla specifically inhibits certain bacteria. Similarly, methanolic extracts of the jellyfish Cassiopeia sp. inhibited some strains of Bacillus and Pseudomonas (Bhosale et al. 2002).

\section{Inhibition of bacterial growth}

Bacteria that responded negatively to fresh Periphylla periphylla generally grew well on autoclaved extract. This suggests that at least one of the compounds inhibiting bacterial growth is of proteinaceous nature and denatured by autoclavation. However, some inhibition occurred also in the autoclaved treatments, albeit with signals of a lower magnitude. For example, the scaling to $P$. periphylla size and body tissue resembled those in the fresh treatments (Figs. 7 \& 8). Thus, several compounds, probably of different nature, likely interact to cause the inhibition. Interestingly, the non-pigmented top dome generated the strongest inhibition (Fig. 8). This tissue is generally low in protein and contains only $\sim 1 / 9$ the amount of protein per unit dry weight relative to the pigmented muscular tissue and tentacles (U. Båmstedt et al. unpubl.). The reddish pigment in $P$. periphylla is porphyrin (Jarms et al. 2002), which becomes toxic to the jellyfish itself and also to many Gram-positive bacteria (but not Gramnegative bacteria) when photoactivated (Malik et al. 1990). Apart from the Actinobacteria (BAL208 and BAL209), all isolates were Gram-negative, among them BAL18 that responded negatively to P. periphylla (Figs. 5 \& 7). The top dome does not contain pigments. Also, our experiments were conducted in darkness to avoid photoactivation. An alternative inhibitor may be nematocyst toxin. Cnidarian nematocyst toxins are generally cytolytic, hemolytic and neurotoxic (Bailey et al. 2003). Analyses of the sodium channel neurotoxin from nematocysts of another cnidarian (a sea anemone, Actinia equina) demonstrated a conserved stretch of residues that were similar to precursors of antimicrobial peptides from frogs (Anderluh et al. 2000). However, in the present study the response to tentacles, where nematocyst density is highest, was less dramatic than to other tissues (Fig. 8). Thus, neither porphyrin nor nematocyst toxin solely explain the inhibitory effects of P. periphylla on bacterial growth. Antimicrobial properties of different tissues may also depend on their enervation (Kasahara \& Bosch 2003). In the freshwater cnidarian Hydra, tissue lacking neurons induced a stronger inhibitory response of strains of Escherichia coli and Bacillus subtilis than did tissue with neurons (Kasahara \& Bosch 2003). Such an explanation may contribute to the strong signal observed for the dome tissue (Fig. 8).

The concentration experiment suggested that the inhibitory compounds generally decreased the maximum sustainable bacterial concentration for BAL208 (Actinobacteria) (Fig. 6, Table 4). The negative effects of increasing Periphylla periphylla concentration exist also for the $\alpha$-Proteobacterium (BAL3), despite its growth being generally higher in the $P$. periphylla 
treatment than in the autoclaved treatment (Fig. 6, Table 4). This indicates that higher concentration of jellyfish compounds (or more dead jellyfish) may negatively affect bacteria that are seemingly unaffected at lower concentrations. The isolates' different growth dynamics were also evident in the 'body part' experiment. The variable response of BAL18 between experiments may stem from variation in P. periphylla sizes used (cf. Fig. 7, Table 2).

While both BAL18 and BAL208 responded negatively to Periphylla periphylla homogenate in general, the response of BAL18 was more pronounced for small $P$. periphylla than for large, while for BAL208, the opposite was the case (Fig. 7). Given that bacterial growth depended on P. periphylla size (Fig. 7), it is possible that additional isolates would have reacted negatively to the $P$. periphylla homogenate had we used a differently sized animal to make homogenate for the initial screening (Fig. 5). P. periphylla size varies over several orders of magnitude $(0.1$ to $\sim 5000 \mathrm{~g}$ wet weight) (Youngbluth \& Båmstedt 2001, Sørnes 2005, Riemann et al. 2006). In addition to being subject to potential differential degradation of various tissues, a dead large $P$. periphylla would thus potentially increase both the power and amount of inhibitory compounds available to sensitive bacteria. Given the variation in bacterial inhibition to various $P$. periphylla sizes, concentrations and tissues, it seems likely that P. periphylla contain several compounds probably both of non-nematocystic (cf. Zhang et al. 2003) and nematocystic origin to which bacteria respond.

\section{CONCLUSION}

Dead jellyfish, and the chemical plumes (cf. Kiørboe \& Jackson 2001) around them, constitute habitats and food for both microorganisms and larger invertebrates. The fate of dead jellyfish and the role of jellyfish as sinks or links in pelagic foodwebs are determined by a combination of (1) physical and chemical constraints preventing or facilitating break-up, degradation and sinking and (2) species-specific suitability as a substrate for microbes and the specific microbial community composition (cf. Riemann et al. 2006). In addition, other studies (Bullard \& Hay 2002) have revealed that (3) species-specific palatability to scavenging animals is also of importance for the fate of dead gelatinous matter.

Acknowledgements. We thank the crews of the RVs 'Haakon Mosby' and 'Hans Brattstrøm', and Vera Ronning for assistance in the field, Umeå Marine Science Centre for CN analyses, and the reviewers for constructive comments. This work formed part of the EUROGEL project funded by the European Commission (EVK3-CT-2002-00074) (U.B., J.T., T.S.). Additional financial support was given by FORMAS (2004-2539) (L.R., J.T.).

\section{LITERATURE CITED}

Alldredge AL (1972) Abandoned larvacean houses, a unique food source in the pelagic environment. Science 177: 885-887

Anderluh G, Podlesek Z, Maček P (2000) A common motif in proparts of Cnidarian toxins and nematocyst collagens and its putative role. Biochim Biophys Acta - Prot Struct Mol Enzymol 1476:372-376

Arai MN (2005) Predation on pelagic coelenterates: a review. J Mar Biol Assoc UK 85:523-536

Bailey PM, Little M, Jelinek GA, Wilce JA (2003) Jellyfish envenoming syndromes: unknown toxic mechanisms and unproven therapies. Med J Aust 178:34-37

Berelson WM (2002) Particle settling rates increase with depth in the ocean. Deep-Sea Res II 49:237-251

Bhosale SH, Nagle VL, Jagtap TG (2002) Antifouling potential of some marine organisms from India against species of Bacillus and Pseudomonas. Mar Biotechnol 4:111-118

Bidle KD, Manganelli M, Azam F (2002) Regulation of oceanic silicon and carbon preservation by temperature control on bacteria. Science 298:1980-1984

Billett DSM, Bett BJ, Jacobs CL, Rouse IP, Wigham BD (2006) Mass deposition of jellyfish in the deep Arabian Sea. Limnol Oceanogr 51:2077-2083

Brodeur RD, Mills CE, Overland JE, Walters GE, Schumacher JD (1999) Evidence for a substantial increase in gelatinous zooplankton in the Bering Sea, with possible links to climate change. Fish Oceanogr 8:296-306

Bullard SG, Hay ME (2002) Palatability of marine macroholoplankton: nematocysts, nutritional quality, and chemistry as defenses against consumers. Limnol Oceanogr 47 : 1456-1467

Davoll PJ, Silver MW (1986) Marine snow aggregates: life history sequence and microbial community of abandoned larvacean houses from Monterey Bay, California. Mar Ecol Prog Ser 33:111-120

Eiane K, Aksnes DL, Bagøien E, Kaartvedt S (1999) Fish or jellies - a question of visibility? Limnol Oceanogr 44: 1352-1357

Fosså JH (1992) Mass occurrence of Periphylla periphylla (Scyphozoa, Coronatae) in a Norwegian fjord. Sarsia 77 : $237-251$

Fuhrman JA, Azam F (1982) Thymidine incorporation as a measure of heterotrophic bacterioplankton production in marine surface waters: evaluation and field results. Mar Biol 66:109-120

Gasol JM, del Giorgio PA (2000) Using flow cytometry for counting natural planktonic bacteria and understanding the structure of planktonic bacterial communities. Sci Mar 64:197-224

Graham WM, Pages F, Hamner WM (2001) A physical context for gelatinous zooplankton aggregations: a review. Hydrobiol 451:199-212

Grasshoff K, Ehrhardt M, Kremling K (1983) Methods of seawater analysis. Verlag Chemie, Weinheim

Grossart HP, Schlingloff A, Bernhard M, Simon M, Brinkhoff $\mathrm{T}$ (2004) Antagonistic activity of bacteria isolated from organic aggregates of the German Wadden Sea. FEMS Microbiol Ecol 47:387-396

Hamner WM, Robison BH (1992) In situ observations of giant appendicularians in Monterey Bay. Deep-Sea Res A 39: 1299-1313

Hansen JLS, Kiørboe T, Alldredge AL (1996) Marine snow derived from abandoned larvacean houses: Sinking rates, particle content and mechanisms of aggregate formation. Mar Ecol Prog Ser 141:205-215 
Hansson LJ (1997) Effect of temperature on growth rate of Aurelia aurita (Cnidaria, Scyphozoa) from Gullmarsfjorden, Sweden. Mar Ecol Prog Ser 161:145-153

Hansson LJ, Norrman B (1995) Release of dissolved organic carbon (DOC) by the scyphozoan jellyfish Aurelia aurita and its potential influence on the production of planktonic bacteria. Mar Biol 121:527-532

Jarms G, Tiemann H, Båmstedt U (2002) Development and biology of Periphylla periphylla (Scyphozoa: Coronatae) in a Norwegian fjord. Mar Biol 141:647-657

Kasahara S, Bosch TCG (2003) Enhanced antibacterial activity in Hydra polyps lacking nerve cells. Dev Comp Immunol 27:79-85

Kiørboe T (2000) Colonization of marine snow aggregates by invertebrate zooplankton: abundance, scaling, and possible role. Limnol Oceanogr 45:479-484

Kiørboe T, Jackson GA (2001) Marine snow, organic solute plumes, and optimal chemosensory behavior of bacteria. Limnol Oceanogr 46:1309-1318

Lee SH, Fuhrman JA (1987) Relationships between biovolume and biomass of naturally derived marine bacterioplankton. Appl Environ Microbiol 53:1298-1303

Lehmann EL (1975) Nonparametrics: Statistical methods based on ranks. Holden-Day, San Francisco, CA

Long RA, Azam F (2001) Antagonistic interactions among marine pelagic bacteria. Appl Environ Microbiol 67: 4975-4983

Lynam CP, Hay SJ, Brierly AS (2004) Interannual variability in abundance of North Sea jellyfish and links to the North Atlantic Oscillation. Limnol Oceanogr 49:637-643

Malik Z, Hanania J, Nitzan Y (1990) Bactericidal effects of photoactivated porphyrins - an alternative approach to antimicrobial drugs. J Photochem Photobiol B 5:281-293

Mills CE (1981) Diversity of swimming behaviors in hydromedusae as related to feeding and utilization of space. Mar Biol 64:185-189

Mills CE (1993) Natural mortality in NE Pacific coastal hydromedusae-grazing predation, wound-healing and senescence. Bull Mar Sci 53:194-203

Mills CE (2001) Jellyfish blooms: Are populations increasing globally in response to changing ocean conditions? Hydrobiol 451:55-68

Noble RT, Fuhrman JA (1998) Use of SYBR Green I for rapid epifluorescence counts of marine viruses and bacteria. Aquat Microb Ecol 14:113-118

Pinhassi J, Hagström $\AA$ (2000) Seasonal succession in marine bacterioplankton. Aquat Microb Ecol 21:245-256

Editorial responsibility: Howard Browman (Associate Editorin-Chief), Storebø, Norway
Pinheiro J, Bates D, DebRoy S, Sarkar D (2005). nlme: linear and nonlinear mixed effects models, $\mathrm{R}$ package version 3.1-65

Purcell JE (1997) Pelagic cnidarians and ctenophores as predators: selective predation, feeding rates, and effects on prey populations. Ann Inst Oceanogr Paris 73:125-137

Purcell JE (2005) Climate effects on formation of jellyfish and ctenophore blooms: a review. J Mar Biol Assoc UK 85: 461-476

Purcell JE, Arai MN (2001) Interactions of pelagic cnidarians and ctenophores with fish: a review. Hydrobiol 451:27-44

Purcell JE, Decker MB (2005) Effects of climate on relative predation by scyphomedusae and ctenophores on copepods in Chesapeake Bay during 1987-2000. Limnol Oceanogr 50:376-387

R Development Core Team (2005) R: a language and environment for statistical computing. The R Foundation for statistical computing, Vienna

Riemann B, Bjørnsen PK, Newell S, Fallon R (1987) Calculation of cell production of coastal marine bacteria based on measured incorporation of $\left({ }^{3} \mathrm{H}\right)$ thymidine. Limnol Oceanogr 32:471-476

Riemann L, Titelman J, Båmstedt U (2006) Links between jellyfish and microbes in a jellyfish dominated fjord. Mar Ecol Prog Ser 325:29-42

Schneider G (1989) The common jellyfish, Aurelia aurita: standing stock, excretion and nutrient regeneration in the Kiel Bight, Western Baltic. Mar Biol 100:507-514

Smith DC, Simon M, Alldredge AL, Azam F (1992) Intense hydrolytic enzyme activity on marine aggregates and implications for rapid particle dissolution. Nature 359: $139-142$

Sørnes T (2005) Visual or tactile zooplanktivores - structuring effects of the underwater visusal environment. $\mathrm{PhD}$ thesis, University of Bergen, Bergen

Stemman L, Jackson GA, Ianson D (2004) A vertical model of particle size distributions and fluxes in the midwater column that includes biological and physical processes Part I: model formulation. Deep Sea Res I 51:865-884

Youngbluth MJ, Båmstedt U (2001) Distribution, abundance, behavior and metabolism of Periphylla periphylla, a mesopelagic coronate medusa in a Norwegian fjord. Hydrobiol 451:321-333

Zhang ML, Fishman Y, Sher D, Zlotkin E (2003) Hydralysin, a novel animal group-selective paralytic and cytolytic protein from a noncnidocystic origin in Hydra. Biochemistry 42:8939-8944

Submitted: May 4, 2005; Accepted: March 31, 2006

Proofs received from author(s): October 24, 2006 